\title{
第19回学術総会/シンポジウム—Symposium 乳がんに対する予防医療
}

名古屋大学大学院医学系研究科予防医学/医学推計 ·判断学

浜島 信之 川合 紗世

要旨：乳がん予防を目的とした医療はわが国ではほとんど行われていないが，欧米では八イリスク者 に対して, 予防的手術(乳房切除, 卵巣切除), 化学予防 (タモキシフェン, ラロキシフェン), 定期的 な検診が実施されている。欧米人で, BRCA1またはBRCA2の遺伝子異常をもつ乳がん未罹患女性 1,383人のうち, $18.0 \%$ が予防的乳房切除術を，49.2\%が卵巣切除術を受けていたことが報告された。 一方，タモキシフェン服用者は5.5\%，ラロキシフェン服用者は2.9\%と比較的少なかった。タモキシ フェンは1998年に，ラロキシフェンは2007年に乳がん予防薬として米国では承認されている。閉経後 のハイリスク女性を対象とした二重盲検無作為割付試験 $(\mathrm{STAR})$ では，ラロキシフェンの乳がん予防 効果は夕モキシフェンと同等で, 子宮内膜がん, 血栓症, 白内障の発生率は夕モキシフェンより低い ことが示された。ラロキシフェンはわが国では骨粗鬆症の薬として保険診療で使用されている。両薬 剂の使用は乳がん予防薬としては保険診療で認められていないことから，わが国ではあまり広がって いない。タモキシフェンはCYP2D6により活性化され,ラロキシフェンはUGT1A1により分解される。 両酵素は遺伝子型により活性が異なることが知られており，今後は，遺伝子型を活用した乳がん予防 医療を模索したい。

索引用語：予防医療，タモキシフェン，ラロキシフェン，遺伝子多型

\section{はじめに}

国立がんセンターのホームページに掲載されている 2003年のデータに基づいたがんの生涯累積罹患率によ ると, 一生の間に男性は $54 \%$, 女性は $41 \%$ \%゙いずれか の部位のがんに罹患すると推計されている(図 1)。女 性乳がんの生涯累積罹患率は $6 \%$ で，18人に 1 人が乳 がんに罹患すると推計される。この生涯累積罹患率は 大腸がん(結腸がんと直腸がんを合わせたもの)より少 ないものの，胃がんとほほ同じで，肺がんより多い。

この生涯累積罹患率は平均值であるから, リスク要 因を持つ女性ではさらに高くなる。図 2 にあよう に, 保因者が非保因者より 2 倍罹患率が高く, その要 因の保因者が $20 \%$ であると仮定すると, 保因者の生涯 累積罹患率は10\%程度となる。また, 保因者が非保因 者より 5 倍罹患率が高く, その要因の保因者が $12.5 \%$ であると仮定すると，保因者の生涯累積罹患率は20\% 程度となる。リスクを半減させる予防法があれば，生

別冊請求先：７466-8550 名古屋市昭和区鶴舞町65 名古屋大学大学院医学系研究科予防医学/ 医学推計 ·判断学 浜島信之

e-mail:nhamajim@med.nagoya-u.ac.jp
涯累積罹患率10\%の場合，20人が予防法を受け入れれ ば 1 人を, 生涯累積罹患率 $20 \%$ の場合, 10 人が予防法 を受け入れれば 1 人を予防することができる。10人の うち 1 人が予防できる方法は, 男性でのピロリ菌感染 者を除菌して胃がんを予防する場合とほぼ同様であ $3^{1)}$ 。

予防医療をめぐる問題点の 1 つとして, リスクの認 識が一般に低く，また人により差があるという点があ る。診断治療では, 実在する疾患への対応となるから 受療への強い動機が形成されるが, 予防医療では動機 が形成されにくい。さらに，わが国の医療保険は原則 として子防のための医療を対象としないから, 予防の ための医療を受けようとすると自由診療となり, 全額 を個人負担しなければならず, 割高となる。また, 保 険診療と自由診療を同時に行うこと(混合診療) はでき ず，多くの医療施設はその実施を躊躇している。診断 治療は存在する疾病に起因する危険を回避するための ものであるため, 有害作用の発生をある程度許容しう るが, 予防医療の場合には有害作用の発生は許容しが たいという問題もある。

\section{I . 欧米での乳がん予防医療}

予防医療には上記のようないくつかの問題点があ 


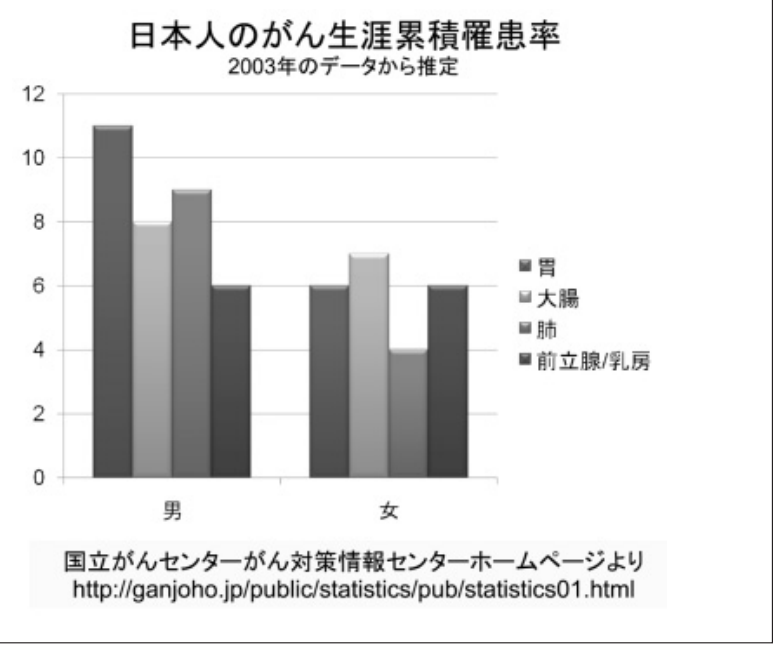

図 1

\section{予防医療をめぐる問題点}

・リスクの個別な推定の不確かさ

生涯累積䍜患率の平均値

女性: すべての部位 41\% 乳がん 6\%

リスク 保因者 生涯累積罹患率 1例の予防に必要な数*

2倍 $20 \% \quad 10 \% \quad 20$ 人

5 倍 $12.5 \% \quad 20 \% \quad 10$ 人

・医療費: 自由診療で割高

・混合診療にあたるかどうかの検討

- 有害作用の発生

り，乳がん予防を目的とした医療はわが国ではほとん ど行われていない。しかし，欧米では乳がん発生率が わが国よりさらに高いこともあり，ハイリスク者に対 しては, 予防的手術 (乳房切除, 卵巣切除), 化学予防 (タモキシフェン，ラロキシフェン)，定期的な検診が 実施されている。

BRCA1または BRCA2の遺伝子に異常をもつ女性で は，乳がん生涯発生率は $45 \sim 87 \%$ と推定されており， その遺伝子検査を受けることができる。同対象者に対 する乳がん予防効果は，乳房切除で95\%，40歳前の卵 巣切除で50\%と推定されており, 夕モキシフェンが乳 がん患者での対側の乳がん予防に有効であることがわ かっている。あとでも紹介する NSABP-P1という研 究では，ゲイルモデルを用いて推定したハイリスク者 に対してタモキシフェンは発生率を半減させた。

実際に，BRCA1または BRCA2の遺伝子異常をもつ 女性が欧米でどのような予防医療を受けているかが調 査された2)。対象者は，米国(703人)，カナダ(766人),
ノルウェイ $(177 人)$, オランダ( 81 人), フランス $(31$ 人), イタリア $(46$ 人), オーストリア(48人), ポーラ ンド $(660$ 人)，イスラエル $(165$ 人)の 9 力国の登録され ていた遺伝子検査時 25 79歳 (平均 45.6 歳)の BRCA1 または BRCA2の遺伝子変異保有者 2,677 人である。遺 伝子検査前に乳がんと診断されていた者と追跡調査中 （面接は1994-05年に実施され，追跡期間は1.5〜10.3 年，平均3.9年)に乳がんと診断された者を除き，乳が んの診断をまだ受けていない 1,383 人の女性について 集計が行われた。予防的乳房切除術を受けていた女性 は18.0\%，卵巣切除術を受けていた女性は49.2\%であ つた。一方，予防的乳房切除術を受けていない女性 1,134 人での夕モキシフェン服用者は 76 人 $(1,383$ 人の

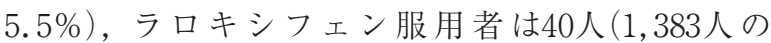
$2.9 \%)$ と比較的少なかった。ノルウェイ，オランダ, フランス,イタリアでは服用者はなく,米国では $12.4 \%$ が2剂のうちいずれかを服用していた。米国で, 乳が ん予防薬としてタモキシフェンが承認されたのは1998 
表 1. 夕モキシフェンの乳がん予防に関する研究

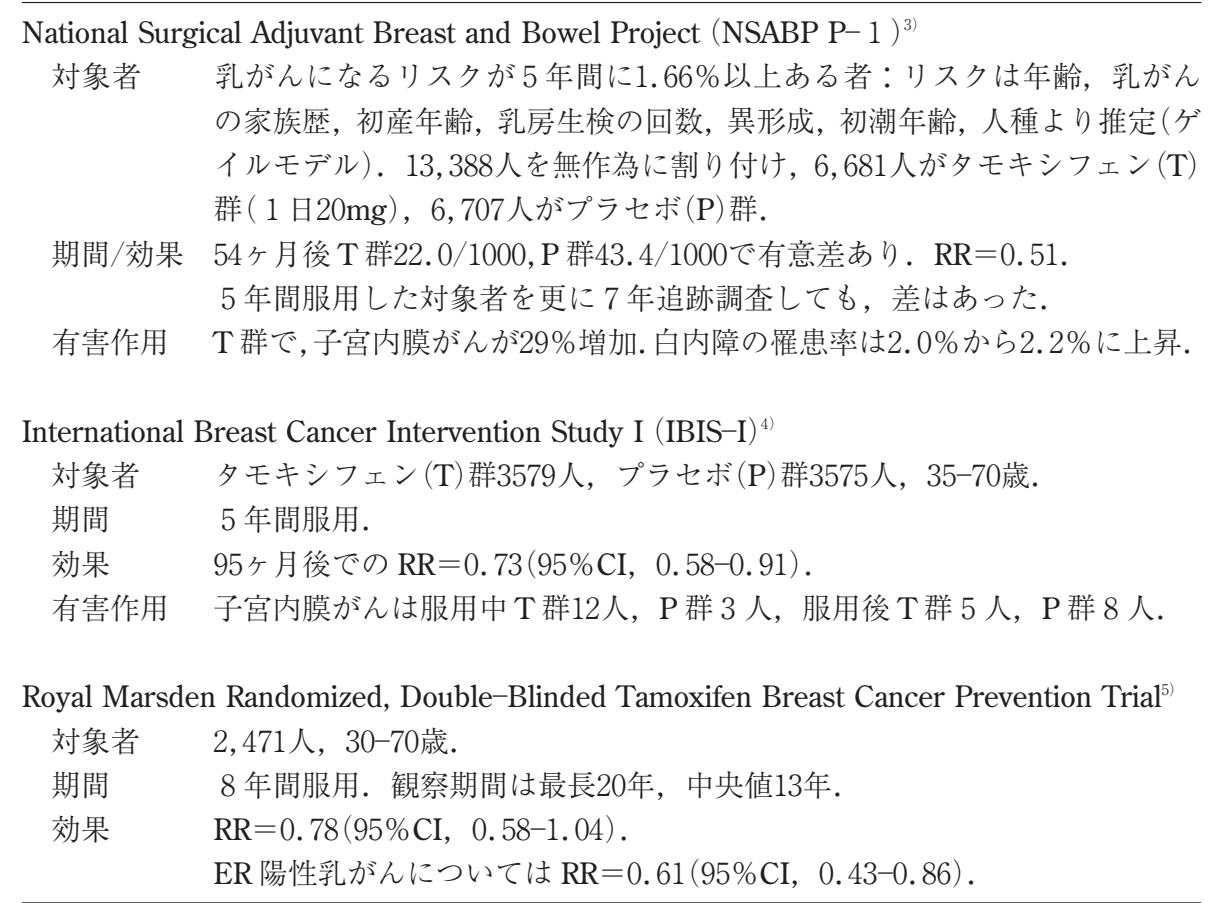

RR：相対危険度，95\%CI：95\%信頼区間

年で，ラロキシフェンが承認されたのは2007年であ る。いずれかの薬剤の服用者は, 卵巣切除術を受けて いた女性(15.6\%)のほうが受けていない女性(1.7\%) に比べ多かった。

\section{II.タモキシフェン(図 3)}

BRCA1または BRCA2の遺伝子異常を持たない女性 にとっては，生涯累積罹患率は50\%を超えるわけでは なく, 予防的手術よりも化学予防のほうが一般的のよ うに思われる。タモキシフェンは抗エストロゲン作用 を持つ薬剂で, 再発予防だけではなく, 乳がん非罹患 者での乳がん予防にも有効であることがいくつかの研 究より確認されている。表 1 に代表的な研究を示す。

National Surgical Adjuvant Breast and Bowel Project P-1 Study (NSABP P-1) としての承認の根拠に使用された研究である。年齢, 乳がんの家族歴, 初産年齢, 乳房生検の回数, 異形成, 初潮年齢, 人種から累積罹患率を推定するゲイルモデ ルにより，5年間の乳がん累積罹患率が $1.66 \%$ 以上あ る者を対象とした大規模無作為化試験である。夕モキ シフェン群とプラセボ群にほぼ同数が割りつけられ, タモキシフェン群での乳がん発生率はプラセボ群のほ ぼ半分であることがわかった。しかし，夕モキシフェ ン群では子宮内膜がんが $29 \%$ 増加していた。 International Breast Cancer Intervention Study I (IBIS -I $)^{4)}$ においても，Royal Marsden Randomized, Double
-Blinded Tamoxifen Breast Cancer Prevention Trial ${ }^{5)}$ においても，乳がん予防の効果は認められている。し かし，夕モキシフェン群における子宮内膜がんの上昇 も間違いのないことであることがわかってきた。 Stockholm Trial, Danish Breast Cancer Group Trial, South-Swedish Trial の 3 つの研究をまとめた推計值 では, 夕モキシフェン群 $(16,318$ 人年中 34 人) は対照群 $(15,773$ 人年中 8 人)に比べ 4.1 倍 $(95 \%$ 信頼区間は $1.9-$ 8.9) 子宮内膜がんの発生率が高かった ${ }^{6)}$ 。

\section{III. ラロキシフェン(図 3)}

ラロキシフェンはわが国では骨粗鬆症の薬として保 険診療で使用されている薬剤で，タモキシフェンと同 様に抗エストロゲン作用を持つ。

表 2 にあるよう，骨粗鬆症に対する効果を調べるこ とを目的とした Multiple Outcomes Raloxifene Evaluation $(\mathrm{MORE})^{7)}$ にて, ラロキシフェン群で乳が んリスクの顕著な減少を認め, 子宮内膜がんのリスク の上昇は観察されなかった。MOREの参加者にさら に 4 年間の服用継続を依頼した Continuing Outcomes Relevant to Evista (CORE) Trail ${ }^{8}$ でも同様な乳がん罹 患率減少効果を認めた。このことから, 夕モキシフェ ンとラロキシフェンの二重盲検無作為化試験である NSABP Study of Tamoxifen and Raloxifen (STAR)P-2 $\mathrm{Trial}^{9}{ }^{9}$ が実施され, ラロキシフェンの乳がんの予防効 果は夕モキシフェンと同程度であり, 子宮内膜がんの 


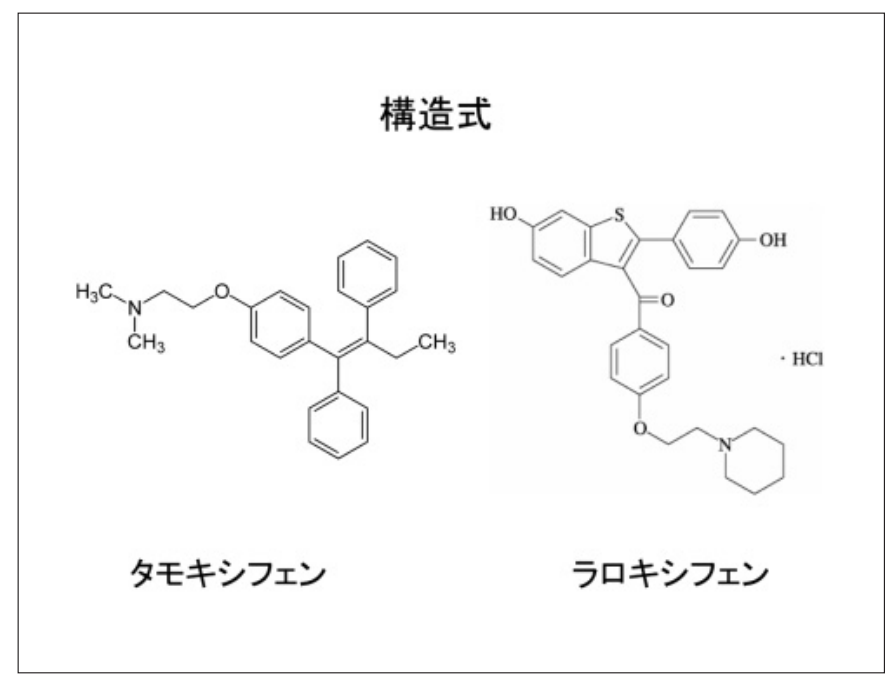

図 3

表 2. ラロキシフェンに関する研究

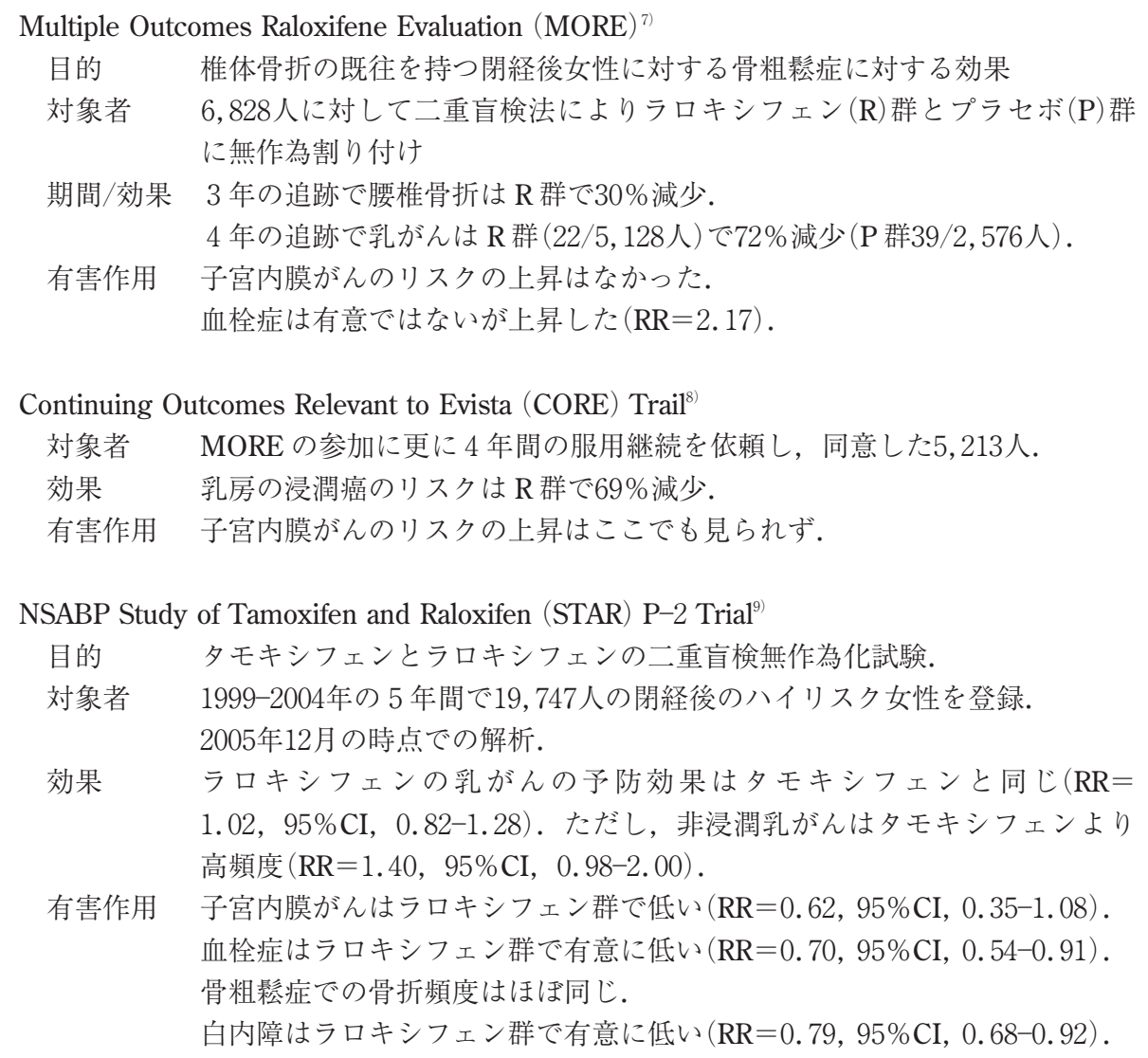

RR：相対危険度，95\%CI：95\%信頼区間

発生はラロキシフェン群で低いことが確認された。こ のことから, タモキシフェンより優れた特性を持つ乳 がん予防薬として米国では認可された。

\section{N．大幸医療センターでの試み}

ラロキシフェンに関する上記の情報に基づいて, 名 古屋大学大幸医療センターで自由診療としてラロキシ フェンの投与を 2007 年 6 月に開始した。日本人に関す
る研究が実施されていない状況ではあったが(現在で もないが), ラロキシフェンは骨粗鬆症薬として日本 で承認されていることから, 大学での倫理審査委員会 の承認を得た上で自由診療として開始した。

対象者は, 表 3 に示す如く閉経後のハイリスク因子 (30歳まで未出産, 良性乳腺疾患既往歴, 乳がん家族 歴)保有女性である。料金は基本料(初診 2,835 円， 2 回目以降1,365円) と薬剤費 (30日分で5, 145円，これに 
表 3. 大幸医療センターでラロキシフェン処方希望者に渡す冊子にある説明文

乳がん予防
ラロキシフェン(エビスタ)服用を希望されます皆様に

薬をお渡しできるのは以下の 1 から 5 の条件をすべて満足する方です.

1. 乳がんの既往が無いこと*.

2. 以下の乳がん高リスク因子を少なくとも1つはあること.

1）30歳までに子供を生んでいない.

2 ）良性乳腺疾患に罹患したことがある.

3 ) 乳がんの家族歴がある(母, 姉妹, 祖母, おば).

3. 受診時に35歳以上79歳までであること.

4. 閉経後であること(閉経後とは，12ヶ月以上月経がない場合, 卵巣子宮全摘術を過去 に受けた場合，55歳以上で子宮全摘術を受けている場合です).

5. 以下の項目すべてに該当しないこと.

1 ）ワーファリン，コレスチラミン，アンピシリンの内服をしている.

2 ) 脳梗塞, 肺梗塞, 心筋梗塞, 深部静脈血栓症の既往がある.

3 ）コントロールのされていない心房細動, 糖尿病, 高血圧がある.

4 ）抗リン脂質抗体症候群の既往がある.

*乳がん既往がある方でもご相談はお受けします.

ラロキシフェンによる予防効果は完全なものではありませんので，定期的に乳がん検診も 受けることをお勧めします。

処方料が加算される)の合計である。本自由診療は新 聞で紹介され，しばらく問い合わせ等があったが，結 局, 受診者は 3 人のみで, 服薬者は 2 人のみであった。 この 2 人も再受診はなく, 処方は 1 回のみとなってい る。ホームページへの掲載は引き続き行っているが, その後の問い合わせはない。わが国における乳がん予 防医療への需要はきわめて限られているというのが現 状である。

\section{CYP2D6 と UGT1A1 の遺伝子多型}

プロドラックであるタモキシフェンは CYP3A4およ びCYP3A5により Nデスメチルタモキシフェンに代 謝され，さらにCYP2D6によりエンドキシフェンに変 換される(図 4)。乳がん予防効果はエンドキシフェン によるものであるため, CYP2D6の活性を持たない人 がタモキシフェンを服用しても乳がん予防効果は期待 できない。CYP2D6には多くの遺伝子多型が知られて おり，＊5 型は遺伝子久損型，＊10型は低活性型 (34 番目のアミノ酸がプロリンからセリンへ, 486番目の アミノ酸がセリンからスレオニンに置換されたもの） である。わが国ではそれぞれアレル頻度が $6.2 \%$ と 37.0\%であることが報告されており ${ }^{10)}$ ，このアレル頻 度から計算すると活性の低い(またはない)者 (* $5 *$ 5 型， * $5 * 10$ 型，＊10*10型)は約19\%存在するこ とになる。タモキシフェンを服用している乳がん患者
での再発率は CYP2D6の低活性型の女性で高いことが 報告されており ${ }^{11,12)}$, 夕モキシフェンを服用する前に, CYP2D6の遺伝子型検査が有用であることがわかって きた。

UGT1A1は塩酸イリノテカンをグルクロン酸抱合し 薬効を低下させるが，この酵素の活性が低い者では有 害作用が強く出る。UGT1A1*6 型と*28型は活性が 低いため, 塩酸イリノテカンを使用する場合には, 検 査することが保険診療として認められている(図 5)。 UGT1A1はラロキシフェンもグルクロン酸抱合するの で，その薬剤効果に影響を与えうる ${ }^{13,14)}$ 。

これらの遺伝子多型検査は, 乳がんの再発予防や発 生予防にタモキシフェンやラロキシフェンを使用する 場合の対象者を選択するのに有用であり, 今後の乳が ん化学予防に新しい視点を与えてくれるものと言え る。

\section{おわりに}

増加傾向にあるわが国の乳がんを予防するには, 適 度な運度, 閉経後の肥満防止など生活習慣の適正化が 有用であるが，八イリスク女性に対する予防医療の選 択肢を広げることも社会にとって有益であろう。日本 においては, 乳がん予防医療はまだ一般的ではない が, 希望者へのラロキシフェン提供, 遺伝子多型検査 によるその対象者の選択など，新たな選択肢が与えら 


\section{タモキシフェンとCYP2D6}

年ギフェシはプロドラッグで活性を持たない。CYP2D6の醉素欠損があると、乳 がん治療効果、予防効果がない。乳がん患者は術後5年間タモキシフェを飲む ことが行われてきた。

CYP2D6 *1 100C (34Pro), 4180G (486Ser) 正常活性型 $39.8 \%$ *5 遺伝子尔損型 $6.2 \%$ *10 100T (34Ser)，4180C (486Thr) 低活性型 37.0\%

Ishiguro et al. Br J Clin Pharmacol 2003:55:413-6

タモキシフェン $\underset{\text { CYP2D6 }}{\rightleftarrows}$ 4ヒドロキシタモキシフェン CYP 3 A $4 / 5$ CYP3A $4 / 5$

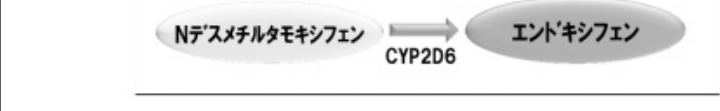

図 4

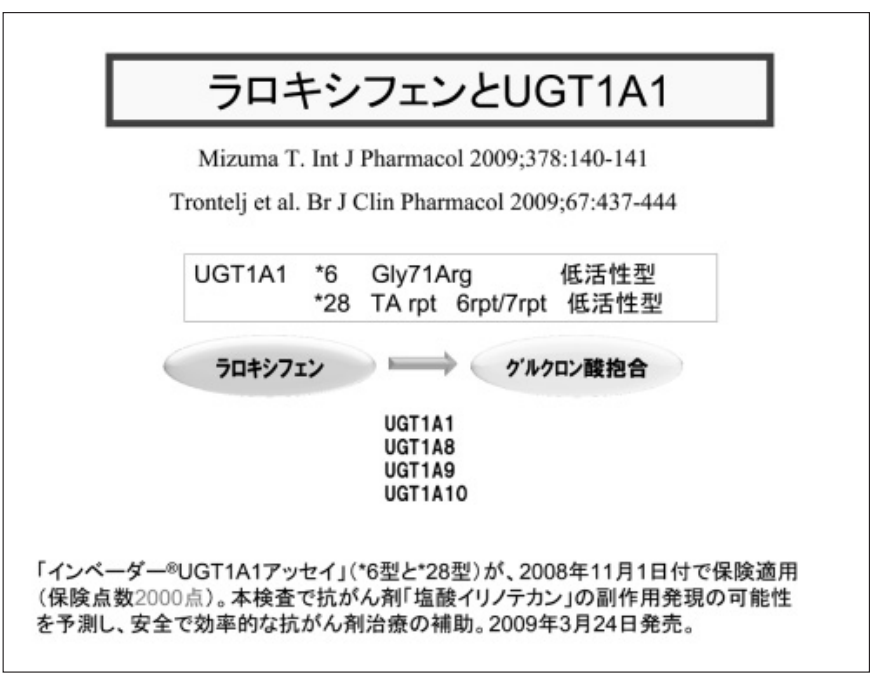

図 5

れたと言える。わが国の医療保険は原則として診断治 療を対象としているため，予防医療実施には制度的な 困難さがあるが，予防医療の提供方法の模索を今後も 行っていきたい。

\section{【文 献】}

1) Hamajima N, Goto Y, Nishio K, et al: Helicobacter pylori eradication as a preventive tool against gastric cancer. Asian Pac J Cancer Prev, 5 :246-252, 2004

2 ) Metcalfe KA, Birenbaum-Carmeli D, Lubinski J, et al: International variation in rates of uptake of preventive options in BRCA 1 and BRCA2 mutation carriers. Int $\mathrm{J}$ Cancer, 122 : 2017-2022， 2008

3 ) Fisher B, Costantino JP, Wickerham DL, et al: Tamoxifen for the prevention of breast cancer: current status of the National Surgical Adjuvant Breast and Bowel Project P-1 study. J Natl Cancer Inst, 97 : 1652 $-1662,2005$

4 ) Cuzick J, Forbes JF, Sestak I, et al: Long-term results tamoxifen prophylaxis for breast cancer-96-month follow-up of the randomized IBIS-I trial. J Natl Cancer Inst, 99 : 272-282, 2007

5 ) Powles TJ, Ashley S, Tidy A, et al: Twenty-year follow -up the Royal Marsden randomized, double-blinded tamoxifen breast cancer prevention trail. J Natl Cancer Inst, 99 : 283-290, 2007

6 ) Rutqvist LE, Johansson H, Signomklao $T$, et al: Adjuvant tamoxifen therapy for early stage breast cancer and second primary malignancies. Stockholm Breast Cance Study Group. J Natl Cancer Inst, 87 : 645-651, 1995

7 ) Ettinger B, Black DM, Mitlak BH, et al: Reduction of vertebral fracture risk in postmenopausal women with osteoporosis treated with raloxifene: results from a 3year randomized clinical trial. Multiple Outcomes of Raloxifene Evaluation (MORE) Inverstigators. JAMA, 282 : 637-645, 1999

8 ) Martino S, Cauley JA, Barrett-Connor E, et al: Continuing outcomes relevant to Evista: breast cancer incidence in postmenopausal osteoporotic women in a randomized trial of raloxifene. J Natl Cancer Inst, 96 : 
1751-1761, 2004

9 ) Vogel VG, Costantino JP, Wickerham DL, et al: Effects of tamoxifen vs raloxifene on the risk of developing invasive breast cancer and other disease outcomes: the NSABP Study of Tamoxifen and Raloxifene (STAR) P-2 trial. JAMA, 295 : 2727-2741, 2006

10) Ishiguro $A$, Kubota $T$, Sasaki $H$, et al: Common mutant alleles of CYP2D6 causing the defect of CYP2 D6 enzyme activity in a Japanese population. Br J Clin Pharmacol, 55 : 414-415, 2003

11) Kiyotani $K$, Mushiroda $T$, Sasa $M$, et al: Impact of CYP2D6 $* 10$ on recurrence-free survival in breast cancer patients receiving adjuvant tamoxifen therapy. Cancer Sci, 99 : 995-999, 2008
12) Hoskins JM, Carey LA, McLeod HL: CYP2D6 and tamoxifen: DNA matters in breast cancer. Nature Rev Cancer, $9: 576-586,2009$

13) Mizuma T: Intestinal glucuronidation metabolism may have a greater impact on oral bioavailability than hepatic glucuronidation metabolism in humans: a study with raloxifene, substrate for UGT1A1, 1A8, 1A9, and 1A10. Int J Pharm, 378 : 140-141, 2009

14) Trontelj J, Marc J, Zavratnik A, et al: Effects of UGT 1 A1 *28 polymorphism on raloxifene pharmacokinetics and pharmacodynamics. Br J Clin Pharmacol, $67: 437$ $-444,2009$

\title{
Medical Services Aimed at Breast Cancer Prevention
}

\author{
Nobuyuki Hamajima, MD, PhD, MPH, Sayo Kawai, MD, PhD \\ Department of Preventive Medicine/Biostatistics and Medical Decision Making, \\ Nagoya University Graduate School of Medicine, Nagoya, Japan
}

Although medical services aimed at prevention of breast cancer are limited in Japan, prophylactic surgery (bilateral oophorectomy or bilateral mastectomy), chemoprevention (tamoxifen or raloxifene), and periodic screening are common in western countries. A study of 1,383 women with a mutation of BRCA1 or BRCA2 before breast cancer diagnosis showed that $18.0 \%$ had undergone bilateral prophylactic mastectomy and $49.2 \%$ had undergone bilateral prophylactic oophorectomy. In that study, 5.5\% of women who did not undergo mastectomy took tamoxifen, and $2.9 \%$ took raloxifene. In the United States, tamoxifen was approved for breast cancer prevention in 1998 and raloxifene in 2007. A double-blind randomized controlled trial for postmenopausal women with a high risk demonstrated that raloxifene was similarly effective in terms of breast cancer prevention, with lower risks of endometrial cancer, thrombosis, and cataract than tamoxifen. Raloxifene has been approved as an anti-osteoporosis drug in Japan. Breast cancer prevention using either drug is not covered by the medical insurance system in Japan, resulting that its prescription is rare. Tamoxifen is activated by CYP2D6 and raloxifene is metabolized by UGT1A1. It is known that the activity of both enzymes is determined by the genotype for each enzyme. Therefore, genotyping of these genes will be an option for breast cancer prevention.

Key words: preventive medical services, tamoxifen, raloxifene, genetic polymorphism 